UNIVERSITY OF COPENHAGEN

\title{
Plant breeding from laboratories to fields
}

Andersen, Sven Bode

DOI:

$10.5772 / 3362$

Publication date:

2013

Document version

Publisher's PDF, also known as Version of record

Citation for published version (APA):

Andersen, S. B. (Ed.) (2013). Plant breeding from laboratories to fields. InTech. https://doi.org/10.5772/3362 


\title{
Chapter 1
}

\section{Genomic in situ Hybridization in Triticeae: A Methodological Approach}

\author{
Sandra Patussi Brammer, Santelmo Vasconcelos, \\ Liane Balvedi Poersch, Ana Rafaela Oliveira and \\ Ana Christina Brasileiro-Vidal \\ Additional information is available at the end of the chapter \\ http://dx.doi.org/10.5772/52928
}

\section{Introduction}

In several plant groups, especially those with polyploid complexes as Triticum (the wheat genus, Poaceae), related species can be used as important sources of genes. In the tribe Triticeae as a whole, which comprises other important cereals as barley (Hordeum vulgare) and rye (Secale cereale), there are high rates of successful interspecific hybridization [1-2]. Due to the ease in obtaining these hybrids, plus the high amount of available information on the genomes of the species, the interspecific hybrids are potentially useful for the genetic improvement of these crops [3-4]. Thus, the hybrids and their derivatives from breeding programs can be analyzed by means of different approaches, aiming the full knowledge on the phenotypic constitution of the plant material for its subsequent utilization.

Many cytogenetic methods can be applied during the process of crop improvement, mainly regarding the characterization of chromosome types among accessions of a germplasm collection [5-6]. Since the discovery of the nucleic acid hybridization reaction by Hall \& Spiegelmann [7], and later by using fluorescent detection rather than radioactive isotopes [8], the fluorescent in situ hybridization (FISH) and its variations have been largely employed in karyotype characterization of plants [9]. The technique basically consists on the pairing of a given probe (a DNA or RNA fragment) with a specific sequence on the target genome, aiming to indicate its exact location in a chromosome.

When the objective is to distinguish parental chromosomes (or chromosome segments) in an interspecific hybridization or the distinct genomes of an allopolyploid, the entire genome of one parent should be labeled and used as probe [10]. In this case, the technique is called genom- 
ic in situ hybridization (GISH). On the other hand, the genome of the second parent (unlabeled) is used as blocking DNA, aiming to avoid non-specific hybridizations due to the similarity of the two parental genomes. Thus, both parental genomes (the probe and the blocking DNA) must be used together in the same hybridization mixture. The proportion probe:blocking DNA should be adequate to avoid the detection of the second parent (see Fig. 1).

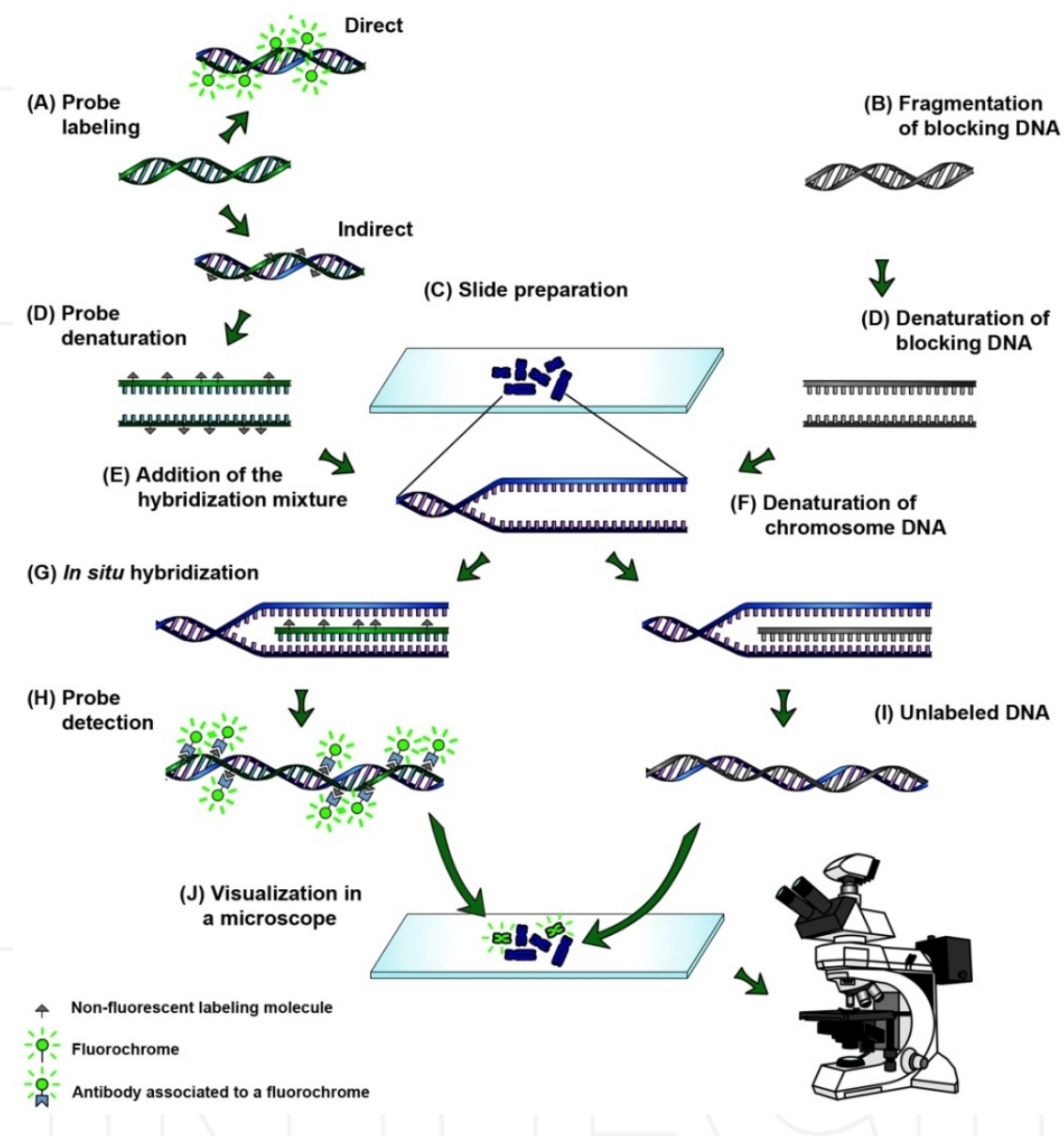

Figure 1. Main steps of the genomic in situ hybridization (GISH). (A) Direct and indirect probe labeling. (B) Fragmentation of the blocking DNA. (C) Slide preparation. (D) Probe and blocking DNA denaturation in a hybridization mixture. (E) Addition of the hybridization mixture with the probe and the blocking DNA. (F) Denaturation of the chromosome DNA. (G) In situ hybridization of probe and blocking DNA in the target sequence of the chromosome. (H) Detection of the probe in the chromosome DNA of one parent, in an indirect labeling. (I) Chromosome DNA molecule of the second parent associated to the unlabeled blocking DNA. (J) Visualization of hybridization signals associated to a probe (green) in a fluorescence microscope. Unmarked chromosomes are visualized with a counter-staining (blue). When the probe labeling is direct, the detection step of the GISH can be excluded. The fluorochromes are the signaling molecules and can be directly visualized in a fluorescence microscope with the appropriate filter. Santelmo Vasconcelos \& Ana C. Brasileiro-Vidal. 
The probe labeling can be either direct or indirect (Fig. 1A). In the direct labeling, the marked nucleotides are associated to fluorochromes, which can be directly visualized in a fluorescence microscope with the proper filter, after in situ hybridization procedures. On the other hand, in the indirect labeling, the marked nucleotides are associated to marker molecules (Fig. 1A), which cannot be visualized in microscopes. Thus, after in situ hybridization procedures, the labeled probes are recognized by antibodies conjugated to fluorochromes, allowing for the probe detection and visualization (Fig. 1J).

The GISH has direct applications on the understanding of the genome evolution of polyploid hybrids, partial allopolyploids and recombinant inbred lines, as well as in detecting the amount of introgressed chromatin during the production of new lineages [11-13]. Therefore, the GISH has efficiently contributed for the analysis on the karyotypic stability of plant materials, indicating the best genotypes, and helping the assisted selection in different phases of crop improvement $[9,14]$.

Here we describe and discuss the main methodological steps of the GISH process as well as the importance of such an approach for the establishment of successful inbred lines, using as example hybrids between common wheat (T. aestivum, $2 n=6 x=42$, AABBDD genome) and rye (S. cereale, $2 n=2 x=14$, RR genome), hexaploid ( $2 n=6 x=42$, AABBRR genome) and octoploid ( $2 n=8 x=56$, AABBDDRR genomes) triticale lines and their derivatives. For this analysis, genomic DNA from rye was used as probe and wheat genomic DNA was used as blocking agent in a proportion of 1:10 (probe:blocking agent). Variations of the technique for other Triticeae species will also be discussed.

\section{DNA isolation (probe and blocking DNA)}

In a GISH, isolating the genomic DNA of the plant materials is the first step for producing the probe and the blocking DNA, being a critical procedure due to the necessity of obtaining DNA as intact as possible and free of contaminants (such as polysaccharides). For plant materials, the DNA isolation can be affected by several factors, such as the procedures for collecting and storing the plant tissue as well as the method for DNA isolation itself. The leaf tissue is the most common to be used for DNA extraction. However, tissues from other parts, as seeds, roots and cultivated cells in suspension, can also be employed.

\subsection{CTAB method from Embrapa Wheat, according to Bonato [15]}

1. Weigh approximately $300 \mathrm{mg}$ of leaf tissue and put in a $1.5 \mathrm{~mL}$ centrifuge tube.

2. Macerate carefully in liquid nitrogen, avoiding defrosting the tissue.

3. Add $700 \mu \mathrm{L}$ of preheated $\left(65^{\circ} \mathrm{C}\right)$ isolation buffer $[2 \% \mathrm{CTAB}, 100 \mathrm{mM}$ Tris- $\mathrm{HCl}(\mathrm{pH} 8.0)$, $20 \mathrm{mM}$ EDTA (pH 8.0) and $1.4 \mathrm{M} \mathrm{NaCl}$ ] and mix well.

4. Incubate the samples for $60 \mathrm{~min}$ at $65^{\circ} \mathrm{C}$ in a water bath. Mix gently every $10 \mathrm{~min}$.

5. Remove from the water bath and let cool to room temperature $\left(\mathrm{ca} .24^{\circ} \mathrm{C}\right)$ for $5 \mathrm{~min}$. 
6. Add $700 \mu \mathrm{L}$ of CIAA (chloroform:isoamyl alcohol, 24:1, v/v). Mix gently for $10 \mathrm{~min}$.

7. Centrifuge for $7 \mathrm{~min}(10,000 \mathrm{rpm}$, room temperature).

8. Transfer the supernatant to new centrifuge tubes and add again $700 \mu \mathrm{L}$ of CIAA. Mix gently for $10 \mathrm{~min}$.

9. Centrifuge for $7 \mathrm{~min}(10,000 \mathrm{rpm}$, room temperature).

10. Transfer the supernatant to new centrifuge tubes and add $500 \mu \mathrm{L}$ of cold $\left(-20^{\circ} \mathrm{C}\right)$ isopropanol, mix gently to precipitate the DNA and incubate for, at least, $30 \mathrm{~min}$ at $-20^{\circ} \mathrm{C}$.

11. Centrifuge for $5 \mathrm{~min}(10,000 \mathrm{rpm}$, room temperature).

12. Discard the supernatant carefully in order to not lose the pellet.

13. Wash the pellet with $600 \mu \mathrm{L}$ of cold $70 \%$ ethanol. Discard the $70 \%$ ethanol.

14. Wash the pellet with $600 \mu \mathrm{L}$ of cold $96 \%$ ethanol. Discard the $96 \%$ ethanol and dry the pellet at room temperature.

15. Re-suspend the pellet in $100 \mu \mathrm{L}$ of $10 \mathrm{mM}$ Tris- $\mathrm{HCl}(\mathrm{pH} 8.0)$ or ultrapure distilled water.

16. Add $3 \mu \mathrm{L}$ of $10 \mathrm{mg} / \mathrm{mL}$ RNase $\mathrm{A}$, mix and incubate for $1 \mathrm{~h}$ at $37^{\circ} \mathrm{C}$.

17. Store samples at $-20^{\circ} \mathrm{C}$ or $-80{ }^{\circ} \mathrm{C}$. For long term conservation, the best results are obtained when pelleted materials are stored in $70 \%$ ethanol.

\subsection{Selective precipitation of polysaccharides, according to Michaels et al. [16]}

1. Add $500 \mu \mathrm{L}$ of the precipitation solution [10 $\mathrm{mM}$ Tris- $\mathrm{HCl}(\mathrm{pH} 8.0)$ and $250 \mathrm{mM} \mathrm{NaCl}$.

2. Dissolve the pellet by vortexing. The complete dissolution of the pellet is important to not lose DNA. Samples with much polysaccharide contamination tend to dissolve more slowly.

3. Add $180 \mu \mathrm{L}$ of cold absolute ethanol. Mix the solution by vortexing and put immediately in chopped ice.

4. Put in the refrigerator $\left(10^{\circ} \mathrm{C}\right)$ for $20 \mathrm{~min}$ or in the freezer $\left(-20^{\circ} \mathrm{C}\right)$ overnight.

5. Centrifuge for $20 \mathrm{~min}\left(10,400 \mathrm{rpm}, 4^{\circ} \mathrm{C}\right)$.

6. Transfer the aqueous phase to a new tube. In this step, the DNA is in the aqueous phase and the pellet may be discarded.

7. Add $700 \mu \mathrm{L}$ of isopropanol and mix gently, inverting the tubes approximately 50 times. Leave the tubes for $15 \mathrm{~min}$ at room temperature.

8. Centrifuge for $20 \mathrm{~min}\left(10,400 \mathrm{rpm}, 4^{\circ} \mathrm{C}\right)$.

9. Discard the supernatant and dry the pellet at room temperature.

10. Add $500 \mu \mathrm{L}$ of $70 \%$ cold ethanol and invert the tube approximately 20 times. 
11. Centrifuge for $20 \mathrm{~min}\left(10,400 \mathrm{rpm}, 4^{\circ} \mathrm{C}\right)$.

12. Discard the supernatant and dry the pellet at room temperature.

13. Re-suspend the pellet in $100 \mu \mathrm{L}$ of $10 \mathrm{mM}$ Tris- $\mathrm{HCl}(\mathrm{pH} 8.0)$ or ultrapure distilled water.

\section{DNA quantification}

After the isolation procedures, the resultant DNA must be quantified prior to probe labeling and preparation of the blocking DNA. Thus, an electrophoresis in agarose gel (0.8\%) with an aliquot of each isolated DNA should be performed, using $\lambda$-DNA as reference with different amounts (e.g. $50 \mathrm{ng}, 100 \mathrm{ng}$ and $150 \mathrm{ng}$ ). After the electrophoretic run, a comparison between reference bands and bands of the isolated DNA can be made. In the sample of the rye DNA (Fig. 2A, sample 2), for instance, it is suggested that the band of the sample presents the same fluorescence intensity of the $100 \mathrm{ng}$ reference $\lambda$-DNA. Thus, as $1 \mu \mathrm{L}$ of the rye DNA was loaded in the gel, then concentration of the isolated rye DNA is $100 \mathrm{ng} / \mu \mathrm{L}$. For the wheat DNA (Fig. 2A sample 1), the band is also similar to the $100 \mathrm{ng}$ reference $\lambda$-DNA. However, in this case, only $0.5 \mu \mathrm{L}$ of the sample where loaded in the gel. Thus, the concentration of the isolated wheat DNA is $200 \mathrm{ng} / \mu \mathrm{L}$.
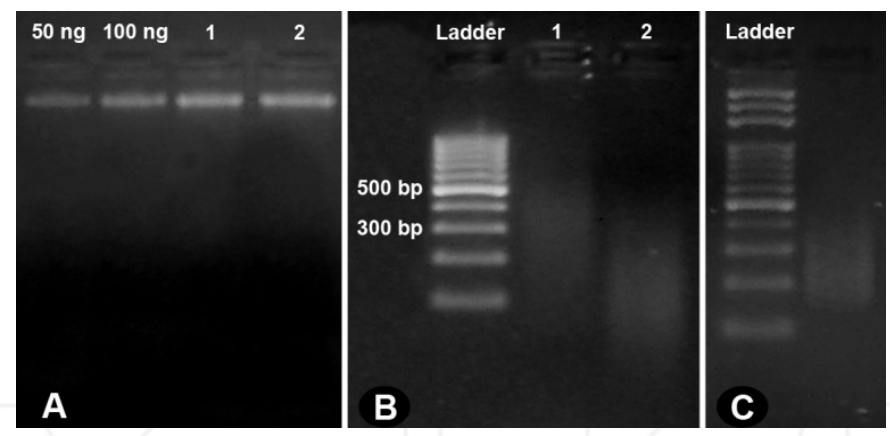

Figure 2. Analysis of genomic DNA by electrophorese in $0.8 \%$ agarose. (A) Quantification of genomic DNA of wheat (sample $1 ; 0.5 \mu \mathrm{L}$ of DNA) and rye (B; sample $2 ; 1 \mu \mathrm{L}$ of DNA). The two first bands are the weight markers with $50 \mathrm{ng}$ and $100 \mathrm{ng}(1 \mu \mathrm{L})$. (B) Verification of the fragmentation of wheat DNA, which will be used as blocking DNA, by autoclaving and (C) rye DNA after labeling by nick translation. The 100 bp DNA ladder was used as marker. Sandra P. Brammer.

\section{Fragmentation of the blocking DNA}

In general, the species involved in the production of hybrids are closely related. Therefore, when a GISH is performed with the genomic DNA of one parental species, a non-specific hybridization often happens in chromosomes derived from the second parental species, 
mainly due to the presence of repetitive DNA that are common between the two parents. In order to avoid this non-specific hybridization, the unlabeled genomic DNA of the second parent should be used in the in situ hybridization. As the probe, the blocking DNA should be approximately $300 \mathrm{bp}$ long, or even shorter (50-300 bp) (Fig. 2B, sample 2). In the specific case of the blocking DNA, the exact amount of DNA of the sample has to be known. Considering the total value of the wheat DNA sample as $100 \mu \mathrm{L}, 99.5 \mu \mathrm{L}$ still remain after the quantification $(100 \mathrm{ng} / \mu \mathrm{L})$. It is important to remember that the DNA should be quantified (total amount in ng or $\mu \mathrm{g}$ ) prior to its fragmentation in autoclave (as explained below), in boiling water, in sonicator or by nick translation (without the marked nucleotides). The DNA fragmentation in autoclave can be made as follows:

1. Prepare an aliquot containing 5-50 $\mu \mathrm{g}$ of the previously quantified DNA in $100 \mu \mathrm{L}$ (diluted in ultrapure distilled water). The sample 1 of the Fig. 2A, for instance, was at 200 $\mathrm{ng} / \mu \mathrm{L}$. Thus, in $100 \mu \mathrm{L}$ of sample there are $19.9 \mu \mathrm{g}$ of DNA.

- Using a $1.5 \mathrm{~mL}$ centrifuge microtube of good quality is recommended to avoid breakage of the tube. To avoid evaporation of the sample, the microtubes should be sealed.

2. Put the microtube in a closed flask to avoid both the opening of the microtube and the direct contact of the sample with the autoclave steam. Put the flask in the autoclave.

3. Turn on the autoclave and when the temperature reaches $121^{\circ} \mathrm{C}$, mark 5 min and then turn it off.

4. After removing the microtube from autoclave, expect the microtube to cool and spin down the volume. Run an electrophoresis with the autoclaved DNA and a $100 \mathrm{bp}$ ladder (as reference) in a $0.8 \%$ agarose gel (Fig. 2B). The fragmented DNA must be between 100-300 bp.

- For GISH in wheat $\times$ rye hybrids, the blocking DNA (wheat DNA) must be at the concentration of $500 \mathrm{ng} / \mu \mathrm{L}$ due to the concentration of the probe of $50 \mathrm{ng} / \mu \mathrm{L}$ (proportion 1:10, probe:blocking DNA). However, for hybrids between other species, the concentration of the blocking DNA may be higher, if the proportion probe:blocking DNA is different. For instance, if the proportion to be used is 1:20, the blocking DNA should be at $1 \mu \mathrm{g} / \mu \mathrm{L}$.

5. Add 2 volumes ( $\mathrm{vol}$ ) of cold absolute ethanol and $0.1 \mathrm{vol}$ of $3 \mathrm{M}$ sodium acetate (or 0.05 vol of $7.5 \mathrm{M}$ sodium acetate) to precipitate the DNA.

6. Mix gently by inverting and store overnight at $-20^{\circ} \mathrm{C}$.

7. Centrifuge for $20 \mathrm{~min}(14,000 \mathrm{rpm}$, room temperature).

8. Wash the pellet with $1 \mathrm{~mL}$ of $70 \%$ ethanol.

9. Centrifuge for $5 \mathrm{~min}(14,000 \mathrm{rpm}$, room temperature).

10. Dry the pellet at room temperature or at $37^{\circ} \mathrm{C}$.

11. Re-suspend the pellet in $10 \mathrm{mM}$ Tris- $\mathrm{HCl}(\mathrm{pH} \mathrm{8.0)}$ or in ultrapure distilled water, in order to reach the required concentration (in this case, $500 \mathrm{ng} / \mu \mathrm{L}$ ). Take into account that there are losses in the total quantity of DNA during the steps of precipitation and resuspension. 


\section{Nick translation}

The procedures of probe labeling by nick translation are performed by using $1 \mu \mathrm{g}$ of DNA. The components that are needed for the labeling reaction are: unmarked nucleotides (dATPs, dCTPs, dGTPs and, in a minor concentration, dTTPs), marked nucleotide (dUTPs) and an enzyme solution with DNase I and DNA polymerase I (Fig. 3A-C). The enzyme DNase I hydrolyzes the DNA by generating random nicks in the double-stranded DNA.

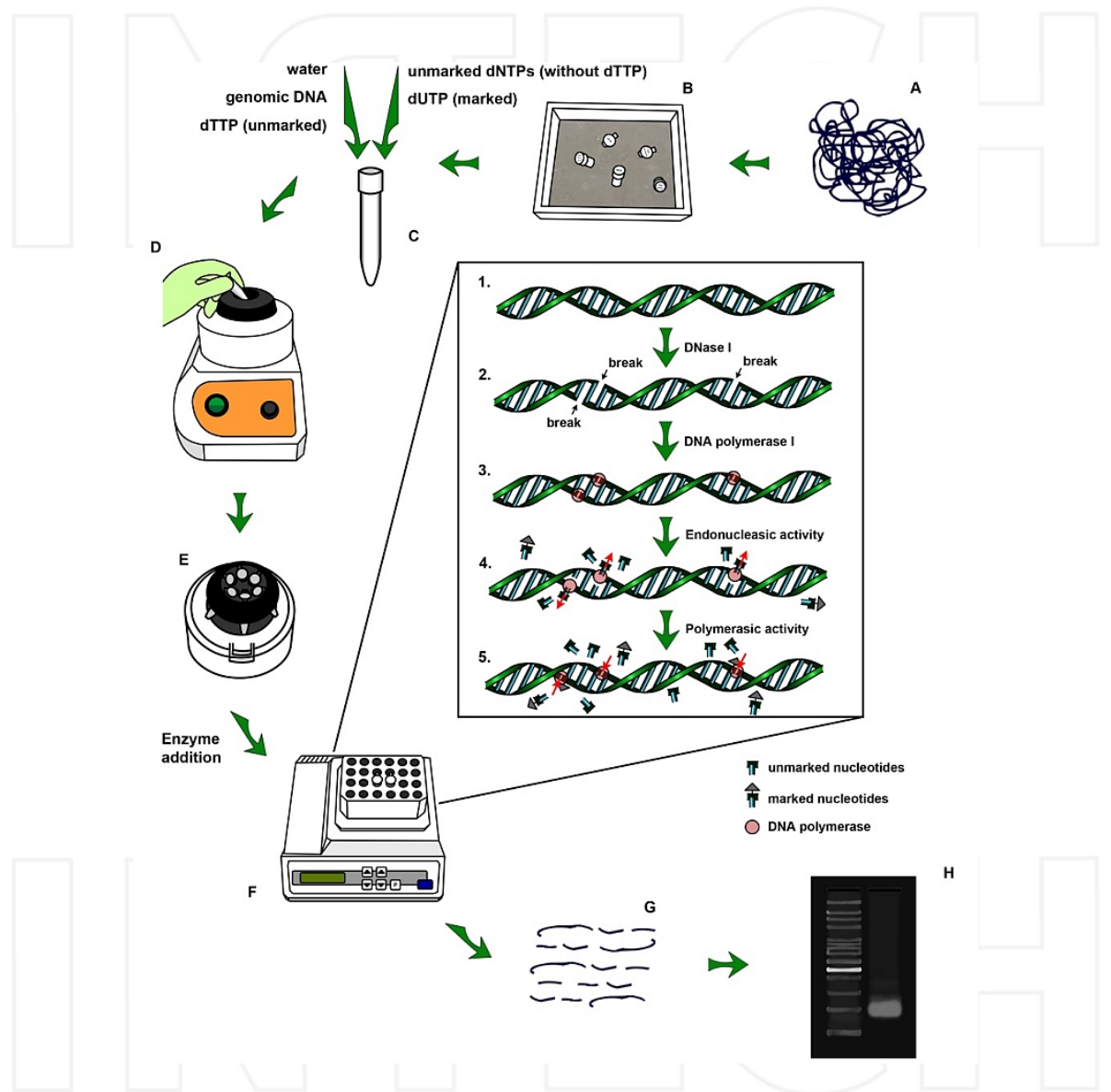

Figure 3. Nick translation reaction. (A) Total genomic DNA to be labeled. (B) Components of the reaction in chopped ice. (C) Preparation of the reaction mixture without the enzymatic solution. (D) The reaction mixture in a vortex. (E) Fast centrifugation of the mixture and addition of the enzymes. (F) Nick translation in a thermoblock at $15-16^{\circ} \mathrm{C}$, according to the manufacturer's recommendation. (G) Fragmented and labeled DNA. (H) Agarose gel showing a fragmented DNA with approximately 200-300 bp. Santelmo Vasconcelos \& Ana C. Brasileiro-Vidal.

- A low number of nicks may lead to an inefficient insertion of marked nucleotides, thus generating larger probes. On the other hand, excessive nicks result in very short probes. 
The DNA polymerase I has three different activities: 1) an exonuclease function that removes nucleotides from the breakage site in the sense $5^{\prime} \cdot 3^{\prime} ; 2$ ) a polymerase function that inserts new nucleotides in the $3^{\prime}$ end, by using the opposite strand as template; and 3) a repair function in the sense $3^{\prime} \cdot 5^{\prime}$. Thus, marked and unmarked nucleotides are incorporated by the new synthesized DNA (see Fig. 3F; [17]). Additionally, only part of the thymines may be replaced by marked uracils. If all thymines are changed, the in situ hybridization reactions could be impaired.

During the nick translation reaction, the DNA structure becomes extremely fragile, resulting in the breakage of the double-stranded DNA. Besides the incorporation of marked nucleotides, the nick translation also fragments the DNA. Therefore, the longer the reaction lasts, smaller the fragments will be. The ideal size for the probe is around 200-300 bp because if it is above $500 \mathrm{bp}$, the in situ hybridization will not work properly; if the probe is much shorter, it could be washed away during the post-hybridization baths. Thus, the size of the fragments must be checked through electrophoresis in agarose gel before stopping the reaction (Figs. 2C, 3G and 3H).

Nick translation reactions are generally performed with commercial labeling kits, which should be performed according to the manufacturer's recommendations, although always following the procedures below:

1. Prepare the nick translation mixture in centrifuge microtube surrounded by chopped ice without the enzymatic solution (Fig. 3B-C).

2. Vortex the mixture, spin down the volume and add the enzymatic solution rapidly (Fig. 3D-E).

3. Mix gently, spin down the volume and put the microtube either in a thermocycler or in a thermoblock at the recommended temperature (Fig. 3F). To find out if the reaction time recommended by the manufacturer was sufficient for obtaining fragments with 200-300 bp, the labeling process should be temporarily suspended by maintaining the tube in chopped ice. Meanwhile, an electrophoresis in $0.8 \%$ agarose gel should be performed with an aliquot of the reaction. If the DNA is sufficiently fragmented (Fig. $3 \mathrm{H}$ ), add the stop buffer. Otherwise, the reaction must continue as long as necessary for correct DNA fragmentation.

4. After adding the stop buffer, add 2 vol of cold absolute ethanol and 0.1 vol of $3 \mathrm{M}$ sodium acetate, in order to precipitate DNA.

5. Mix gently by inverting and put in the freezer overnight.

6. Centrifuge for $20 \mathrm{~min}(14,000 \mathrm{rpm}$, room temperature), discard the supernatant and add $1 \mathrm{~mL}$ of $70 \%$ ethanol.

7. Centrifuge for $5 \mathrm{~min}(12,000 \mathrm{rpm}$, room temperature), discard the supernatant and dry the pellet at room temperature or at $37^{\circ} \mathrm{C}$.

8. Re-suspend the pellet in $15-20 \mu \mathrm{L}$ of $10 \mathrm{mM}$ Tris- $\mathrm{HCl}(\mathrm{pH} 8.0)$ and store at $-20^{\circ} \mathrm{C}$. 


\section{Seed germination and collecting, pretreating and fixating root tips}

1. Wash seeds in $4 \%$ chlorine bleach for 5 min (Fig. $4 \mathrm{~A}$ ).

2. Wash seeds three times with distilled water for 5 min each (Fig. 4A).

3. Put seeds in Petri dishes with cotton and filter paper moistened with distilled water and incubate for $24 \mathrm{~h}$ at $25^{\circ} \mathrm{C}$.

4. Transfer the Petri dishes to a refrigerator $\left(4^{\circ} \mathrm{C}\right)$ for $48 \mathrm{~h}$ and then incubate again for $24 \mathrm{~h}$ at $25{ }^{\circ} \mathrm{C}$. The low temperature promotes cell synchronization. Then, when the cells are restored to $25^{\circ} \mathrm{C}$, the cellular cycle is fully synchronized, thus increasing the amount of metaphases per slide.

5. The following day, collect root tips with a length of 1 to 1.5 times the size of the seed (Fig. 4B). The number of cells obtained during slide preparation is greatly increased when root tips are collected in the morning. Nevertheless, if some roots are still too small, let them grow a little more to collect later.

6. Pretreat the root tips in a 1.5 centrifuge tube containing ultrapure distilled water for 24 $\mathrm{h}$ at $4{ }^{\circ} \mathrm{C}$ (Fig. 4C). Add no more than six roots per tube. During this step, the tubes must be open because the roots are still alive and they need oxygen. The cold pretreatment is performed to increase the number of cells in metaphase. If there are many cells in anaphase and telophase, it means that the pretreatment did not work properly.

7. Fixate the root tips in Carnoy (absolute ethanol:acetic acid, 3:1, v/v) for $24 \mathrm{~h}$ at room temperature (Fig. 4D). Excellent quality products must be used in this step. Maintain the tubes under stirring during the first $90 \mathrm{~min}$ for a better fixation.

8. Store the root tips at $-20^{\circ} \mathrm{C}$ until use. Preferably, use newly fixed root tips.

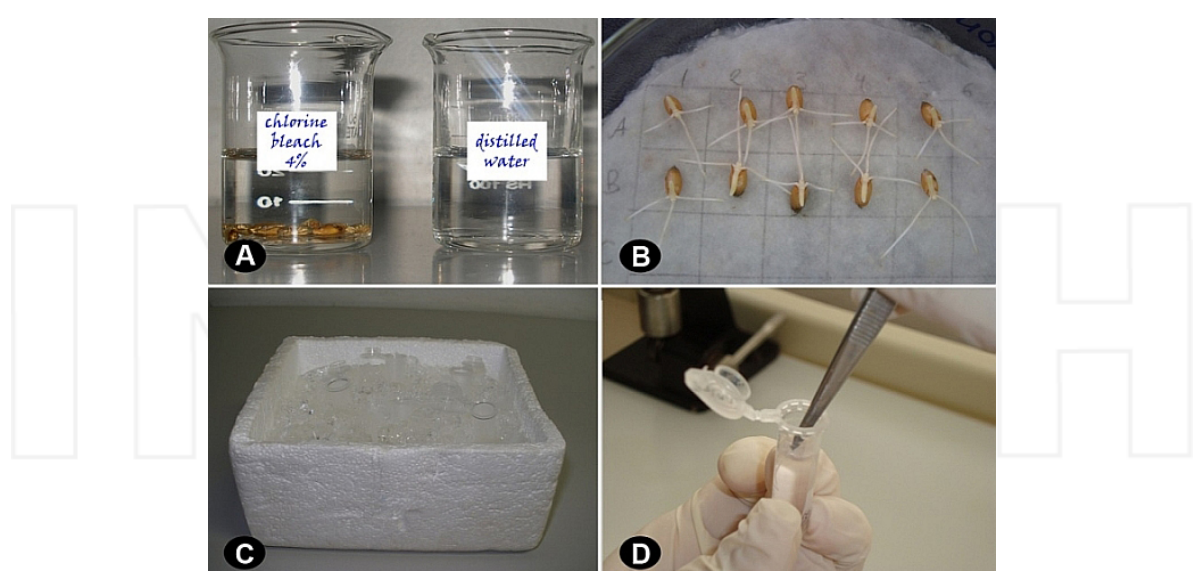

Figure 4. Washing and germinating seeds in (A) and (B); pretreatment and fixation of root tips in (C) and (D). (A) Seed washing in $4 \%$ chlorine bleach. (B) Roots with the length of 1 to 1.5 times the size of the seed, adequate for the collection. (C) Cold pretreatment of root tips. (D) Fixation of root tips in absolute ethanol:acetic acid (3:1, v/v). A and C: Ana R. Oliveira \& Ana C. Brasileiro-Vidal; B and D: Sandra P. Brammer. 


\section{Slide preparation}

Before starting this step, it is important to treat the slides, as in $6 \mathrm{~N} \mathrm{HCl}$ for at least $6 \mathrm{~h}$, for instance. Then, wash the slides under flowing water for $15 \mathrm{~min}$, dip in distilled water and store in absolute ethanol until use.

1. Wash fixed root tips twice in a Petri dish with distilled water for 5 min each.

2. Digest the root tips in a $2 \%$ cellulase and $20 \%$ pectinase solution at $37{ }^{\circ} \mathrm{C}$ for $30-90 \mathrm{~min}$, depending on the potential of the enzymatic activity. Digest only one root tip per slide by using high quality enzymes. Use a stereoscopic microscope to remove the root cap, add a drop of the enzymatic solution (ca. $5-10 \mu \mathrm{L}$ ) and incubate at $37^{\circ} \mathrm{C}$.

3. Wash the digested meristems twice with distilled water for $5 \mathrm{~min}$ each. For each wash, dry the root tips with filter paper without touching the digested material to avoid damaging it (Fig. 5D). Add a drop of distilled water carefully with a Pasteur pipette.

4. Add a drop of $45 \%$ acetic acid for, at least, $20 \mathrm{~min}$ (Fig. 5E). Afterwards, remove the acetic acid with filter paper and add a drop of distilled water either for $20 \mathrm{~min}$ (at least) at room temperature or overnight in a moisture chamber at $4-10{ }^{\circ} \mathrm{C}$ (in the refrigerator). Then, dry the root tips and add again a drop of $45 \%$ acetic acid and maintain the slides in a moisture chamber until use. Follow the step 5 for each slide individually.

5. With the aid of a stereoscopic microscope, disrupt completely the meristem with two histological needles, (Fig. 5F). Do not let the material dry. If this starts to happen, add carefully a little more $45 \%$ acetic acid. It is important to notice that the quantity of acetic acid used during this step is very critical for obtaining high quality preparations. Too much acid will lead to the loss of material; if too little acid is used, there will be air bubbles, which will negatively affect the quality of the slides.

6. Put an $18 \times 18 \mathrm{~mm}$ glass coverslip over the material and tap gently with a blunt tip needle (Fig. 5G-H). While tapping, hold the coverslip with a piece of folded filter paper to avoid cell damage caused by slippage of the coverslip. In a bright field optical microscope, always observe the distribution of the material after and before tapping. This measure is important to determine how intense the tapping must be. A too intense tapping may break drastically the cells and cause chromosome losses. On the other hand, if the tapping is too weak, the material will not spread properly. The ideal condition is when the cells are broken, but all chromosomes are still in a same field of view in the microscope.

7. Heat the preparation in an alcohol Bunsen burner ca. three times, carefully to prevent boiling (Fig. 5I). Fell the temperature with the back of the hand.

8. Then smash the material thoroughly. Put the slide-coverslip set within two sheets of folded filter paper and press with a thumb always taking precaution not to move coverslip (Fig. 5J).

9. Dip the slide-coverslip set in liquid nitrogen for approximately $3 \mathrm{~min}$ (Fig. 5K). 
10. Quickly remove the coverslip with the aid of a steel blade or a bistoury (Fig. 5L). The liquid nitrogen freezes the slide-coverslip set. Because the slide is thicker, it takes longer to warm up in comparison to the coverslip. Thus, the chromosomes will be attached to the coldest part (the slide) when the coverslip is removed. However, if there is a delay to remove the coverslip, chromosomes may be lost or in two planes in the slide.

11. Let the slides to dry off inclined.

12. Store the slides at $-20^{\circ} \mathrm{C}$ (or, if possible, at $-80^{\circ} \mathrm{C}$ ) for an indefinite period until the in situ hybridization procedures. The results of the GISH will be better when newly prepared slides are used.

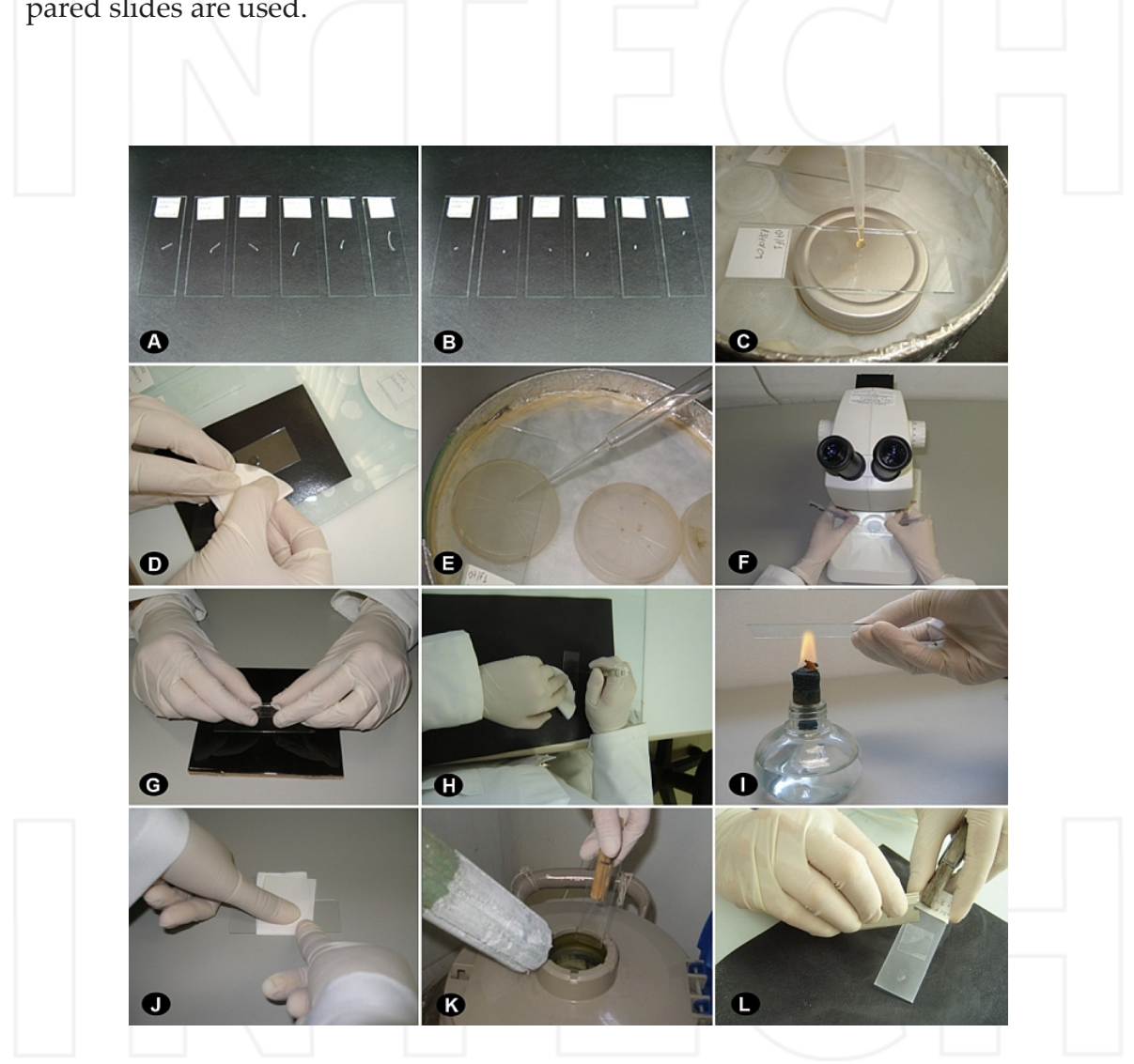

Figure 5. Preparation of slides for genomic in situ hybridization. (A) Full length root tips after washing in distilled water. (B) Root meristem to be digested. (C) Enzymatic digestion. (D) Removal of the enzymatic solution. (E) Addition of $45 \%$ acetic acid. (F) Disruption of the root meristem, with histological needles in a stereoscopic microscope. (G) Addition of an $18 \times 18 \mathrm{~mm}$ coverslip. (H) Gentle tapping with a blunt tip needle. (I) Quick heating of the preparation in an alcohol Bunsen burner. (J) Squashing of the slide-coverslip set with two sheets of filter paper. (K) Dipping the slidecoverslip set in liquid nitrogen. (L) Quick removal of the coverslip. A, B, C, F, H, J, K and L: Sandra P. Brammer; D, E, G and I: Ana R. Oliveira \& Ana C. Brasileiro-Vidal. 


\section{Genomic in situ hybridization}

\subsection{Treatment of slides}

Prior to the beginning of the GISH procedures, identify the slides and mark preparation area with a diamond-tipped pen (or similar), along the length of the blade (Fig. 6A). Avoid doing notes with permanent marker or using paper labels.

Slides stored for a long time must be dipped in Carnoy for $15 \mathrm{~min}$, followed by an alcoholic series of $70 \%$ and $100 \%$ ethanol for 5 min each (Fig. 6B). The Carnoy helps to better fix the chromosome structure. However, this step is not necessary for newly prepared slides.

1. Let the slides to dry off for $30 \mathrm{~min}$ at $50-60{ }^{\circ} \mathrm{C}$ (Fig. 6C). This drying is important because the grip of the chromosomes to the blade is improved during the process.

- Paraformaldehyde to be used at step 8 could be prepared during the steps 1-2.

2. Let the slides to cool for 5-10 min at room temperature (Fig. 6D).

3. Add $50 \mu \mathrm{L}$ of $100 \mu \mathrm{g} / \mathrm{mL}$ RNase A [a $10 \mathrm{mg} / \mathrm{mL}$ RNase A solution diluted in $2 \times \mathrm{SSC}$ (300 $\mathrm{mM} \mathrm{NaCl}$ and $30 \mathrm{mM} \mathrm{Na}_{3} \mathrm{C}_{6} \mathrm{H}_{5} \mathrm{O}_{7} \cdot 2 \mathrm{H}_{2} \mathrm{O}$ ) at the proportion of $\left.1: 100\right]$, cover with a plastic coverslip (made of laboratory film or similar) and incubate in a moisture chamber for 1 $h$ at $37^{\circ} \mathrm{C}$ (Fig. 6E-F).

4. Wash the slides three times in $2 \times \mathrm{SSC}$ for $5 \mathrm{~min}$ each (Fig. 6G). After each wash cycle, the used volume of $2 \times$ SSC must be replaced by a clean one.

5. Add $50 \mu \mathrm{L}$ of $10 \mathrm{mM} \mathrm{HCl}$, cover with plastic coverslip and maintain for $5 \mathrm{~min}$ (Fig. $6 \mathrm{H}$ ).

6. Add $50 \mu \mathrm{L}$ of $15 \mu \mathrm{g} / \mathrm{mL}$ pepsin (a $1 \mathrm{mg} / \mathrm{mL}$ pepsin solution diluted in $10 \mathrm{mM} \mathrm{HCl}$ at the proportion of 1.5:100), cover with plastic coverslip and incubate at $37^{\circ} \mathrm{C}$ for $20 \mathrm{~min}$ (Fig. 6I-J). Before adding the pepsin solution, remove the excess of $\mathrm{HCl}$ with and absorbing paper as illustrated in Fig. 6M.

7. Wash the slides three times in $2 \times$ SSC for 5 min each (Fig. $6 \mathrm{~K}$ ).

8. Fixate the chromosome preparation in $4 \%$ paraformaldehyde for $10 \mathrm{~min}$ (Fig. $6 \mathrm{~L}$ ). Be extremely cautious when handling paraformaldehyde because it is highly toxic and carcinogenic.

9. Wash the slides three times in $2 \times \mathrm{SSC}$ for 5 min each (Fig. 6L).

- In general, for Triticeae species, the procedures from step 3 to 9 may be completely excluded without affecting the in situ hybridization.

10. Dehydrate the slides in an alcoholic series of $70 \%$ and $100 \%$ ethanol for 3 min each (Fig. $6 \mathrm{M}-\mathrm{N})$.

11. Let the slides to dry off for, at least, $1 \mathrm{~h}$ at room temperature (Fig. 6O). 


\subsection{In situ hybridization according to Heslop-Harrison et al. [18] and Pedrosa et al. [19], with some modifications}

The stringency value for the procedures below is $77 \%$. The stringency value refers to the percentage of correct base pairing during the in situ hybridization process and is calculated according to formamide and salt (SSC) concentrations in the solution, as well as the reaction temperature [17]. Defrost all components and prepare the hybridization mixture in chopped ice (Fig. 7A).

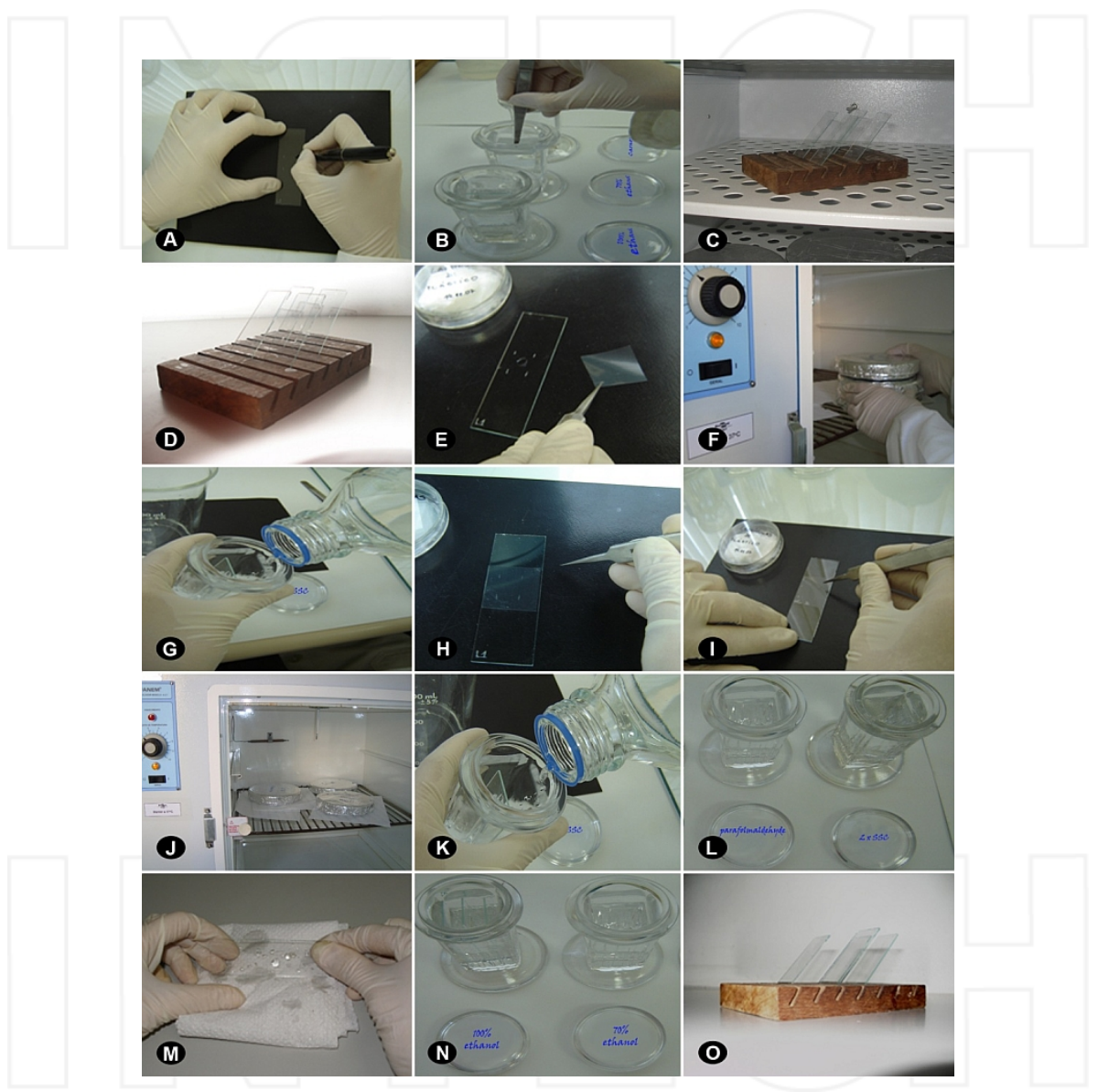

Figure 6. Slide treatment for genomic in situ hybridization. (A) Marking the area of the slide that contains the chromosome preparation. (B) Baths in absolute ethanol:acetic acid (3:1, v/v), $70 \%$ ethanol and $100 \%$ ethanol. (C) Drying slides in an incubation oven at $50-60^{\circ} \mathrm{C}$. (D) Slides in room temperature. (E) Digestion with RNase. (F) Incubation of the slides at 37 ${ }^{\circ} \mathrm{C}$ in a moisture chamber. (G) Washing the slides in $2 \times S S C$ to remove the RNase. (H) Addition of $10 \mathrm{mM} \mathrm{HCl}$. (I) Digestion with pepsin. (J) Incubation of the slides at $37^{\circ} \mathrm{C}$ in a moisture chamber. (K) Washing the slides in $2 \times S S C$. (L) Treatment with $4 \%$ paraformaldehyde and posterior washes in $2 \times S S C$. (M) Removal of the excess of $2 \times S S C$ with absorbing paper. (N) Dehydration in an alcoholic series (70\% and 100\%). (O) Drying the slides at room temperature. A, B, E, F, G, H, I, J, K, L, M and N: Sandra P. Brammer; C, D and O: Ana R. Oliveira \& Ana C. Brasileiro-Vidal. 


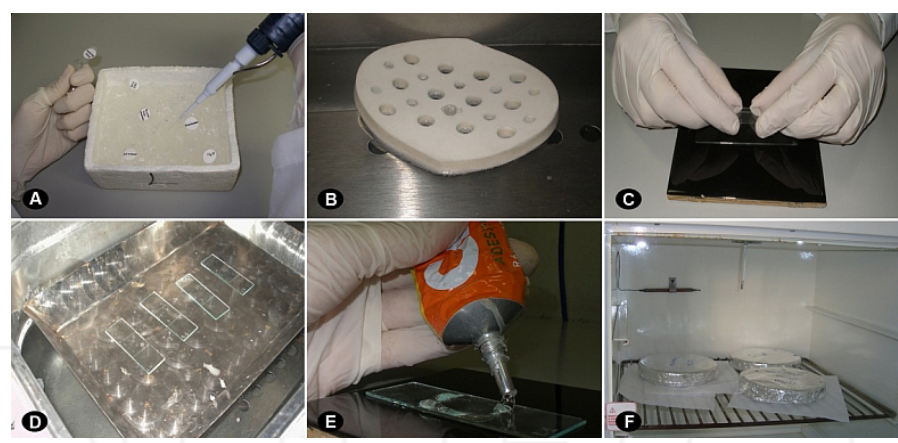

Figure 7. Genomic in situ hybridization. (A) Preparation of the hybridization mixture. (B) Denaturation of the probe at $75{ }^{\circ} \mathrm{C}$. (C) Addition of the hybridization mixture in the chromosome preparation and covering with a glass coverslip. (D) Denaturation of the chromosomes in a metal plate inside a water bath at $73^{\circ} \mathrm{C}$. (E) Sealing the coverslip with rubber glue. (F) In situ hybridization at $37{ }^{\circ} \mathrm{C}$. A, B, C, D and E: Ana R. Oliveira \& Ana C. Brasileiro-Vidal; F: Sandra P. Brammer.

1. Prepare the hybridization mixture ( $50 \%$ formamide, $10 \%$ dextran sulfate, $2 \times$ SSC, ca. $2.5-5 \mathrm{ng} / \mu \mathrm{L}$ of probe and $25-50 \mathrm{ng} / \mu \mathrm{L}$ of blocking) with a final volume of $10 \mu \mathrm{L}$ per slide (Table 1). In case of using directly labeled probes, the mixture preparation and all the following steps must be done in partial darkness (avoid direct incidence of light). The formamide destabilizes the DNA molecule, helping in the denaturation. Thus, be careful while handling it due to its high toxicity.

2. For probe denaturing, incubate the mixture at $75^{\circ} \mathrm{C}$ for $10 \mathrm{~min}$ in a water bath (Figs. 1D and $7 \mathrm{~B}$ ). Immediately put the mixture on ice for at least 5 min to keep the two DNA strands open.

3. Spin down the mixture and then add $10 \mu \mathrm{L}$ per slide, cover with an $18 \times 18$ glass coverslip and denature the slide at $73^{\circ} \mathrm{C}$ for $10 \mathrm{~min}$ (Figs. $1 \mathrm{E}-\mathrm{F}$ and $7 \mathrm{C}$ ).

- For other plant groups, use $75^{\circ} \mathrm{C}$ or above.

4. Seal the coverslip with rubber glue (Fig. 7E) and incubate the slide in a moisture chamber at $37^{\circ} \mathrm{C}$ overnight (ca. $16 \mathrm{~h}$ ) or up to one day and a half (Figs. $1 \mathrm{G}$ and $7 \mathrm{~F}$ ).

\begin{tabular}{ccc}
\hline Component & Quantity & Final concentration \\
\hline $100 \%$ formamide & $5 \mu \mathrm{L}$ & $50 \%$ \\
\hline $50 \%$ dextran sulfate & $2 \mu \mathrm{L}$ & $10 \%$ \\
\hline $20 \times S S C$ (saline-sodium citrate) & $1 \mu \mathrm{L}$ & $2 \times$ \\
\hline Probe & $0.5-1 \mu \mathrm{L}$ & ca. $2.5-5 \mathrm{ng} / \mu \mathrm{L}$ \\
\hline Blocking DNA & $0.5-1 \mu \mathrm{L}$ & ca. $25-50 \mathrm{ng} / \mu \mathrm{L}$ \\
\hline Ultrapure distilled water & Q.s.p. $10 \mu \mathrm{L}$ & - \\
\hline
\end{tabular}

Table 1. Components of a $10 \mu \mathrm{L}$ hybridization mixture. 


\subsection{Post-hybridization baths and probe detection}

In this step, flasks with SSC solutions and the Coplin jar (with the solution of the first wash) must be previously in the water bath at $42{ }^{\circ} \mathrm{C}$ (Fig. 8A). Before the temperature of the water bath, the temperature inside the Coplin jar must also be checked. The same jar can be used for all baths by discarding the anterior SSC solution and adding the next one (Fig. 8B-C). Furthermore, the function of the wash procedures is to remove the excess of material from the in situ hybridization, mainly non-hybridized probes and incorrectly hybridized ones.

1. Remove the rubber glue with tweezers without moving the coverslip.

2. Dip the slides with the coverslips in the pre-warmed Coplin jar. After dipping the last slide, remove carefully the coverslips to avoid damage to the chromosomes. The time count begins only after the last coverslip is removed.

3. Wash the slides twice in $2 \times \mathrm{SSC}$ for 5 min each at $42{ }^{\circ} \mathrm{C}$.

4. Wash the slides twice in $0.1 \times \mathrm{SSC}\left(15 \mathrm{mM} \mathrm{NaCl}\right.$ and $\left.1.5 \mathrm{mM} \mathrm{Na}_{3} \mathrm{C}_{6} \mathrm{H}_{5} \mathrm{O}_{7} \cdot 2 \mathrm{H}_{2} \mathrm{O}\right)$ for $5 \mathrm{~min}$ (stringency of $73 \%$ ) at $42{ }^{\circ} \mathrm{C}$.

5. Wash the slides twice in $2 \times \mathrm{SSC}$ for 5 min each at $42{ }^{\circ} \mathrm{C}$. In the second wash, remove the Coplin jar from the water bath.

6. Wash the slides once in $2 \times \mathrm{SSC}$ for $5 \mathrm{~min}$ at room temperature.

7. Wash the slides once in $4 \times \mathrm{SSC}+0.1 \%$ Tween $20(600 \mathrm{mM} \mathrm{NaCl}, 60 \mathrm{mM}$ $\mathrm{Na}_{3} \mathrm{C}_{6} \mathrm{H}_{5} \mathrm{O}_{7} \cdot 2 \mathrm{H}_{2} \mathrm{O}$ and $0.1 \%$ Tween 20 ) at room temperature.

During the washes of slides with directly labeled probes, the procedures must also be done in partial darkness due to the presence of fluorochromes. Moreover, the GISH procedures end after these washes when using this type of probes and the results may be already visualized in an epifluorescence microscope after adding the DAPI-Vectashield, as better explained below in the steps 11-12 (Fig. 1J).

1. Dry the excess of SSC, add the secondary antibody mixture (antibody and $1 \%$ BSA in $4 \times \mathrm{SSC}+0.1 \%$ Tween 20 , according to the manufacturer's recommendation), cover with a plastic coverslip and incubate at $37^{\circ} \mathrm{C}$ for $1 \mathrm{~h}$ in a dark moisture chamber.

2. Wash the slides three times for 10 min each in $4 \times \mathrm{SSC}+0.1 \%$ Tween 20 at $42{ }^{\circ} \mathrm{C}$. These washes are needed for removing the excess of antibodies.

3. Dry the excess of SSC, add $8 \mu \mathrm{L}$ of DAPI (4',6-diamidino-2-phenylindole; $2 \mu \mathrm{g} / \mathrm{mL})$ and Vectashield anti-fade $(1: 1, \mathrm{v} / \mathrm{v})$ and mount the slide with a $22 \times 22$ glass coverslip (Fig. $8 \mathrm{~J}$ $\mathrm{K})$. Seal the coverslip with colorless nail polish and allow it to dry for at least $1 \mathrm{~h}$ in the dark (Fig. 8L).

4. Analyze the slides in an epifluorescence microscope with the adequate fluorescence filter (Fig. 1J). 


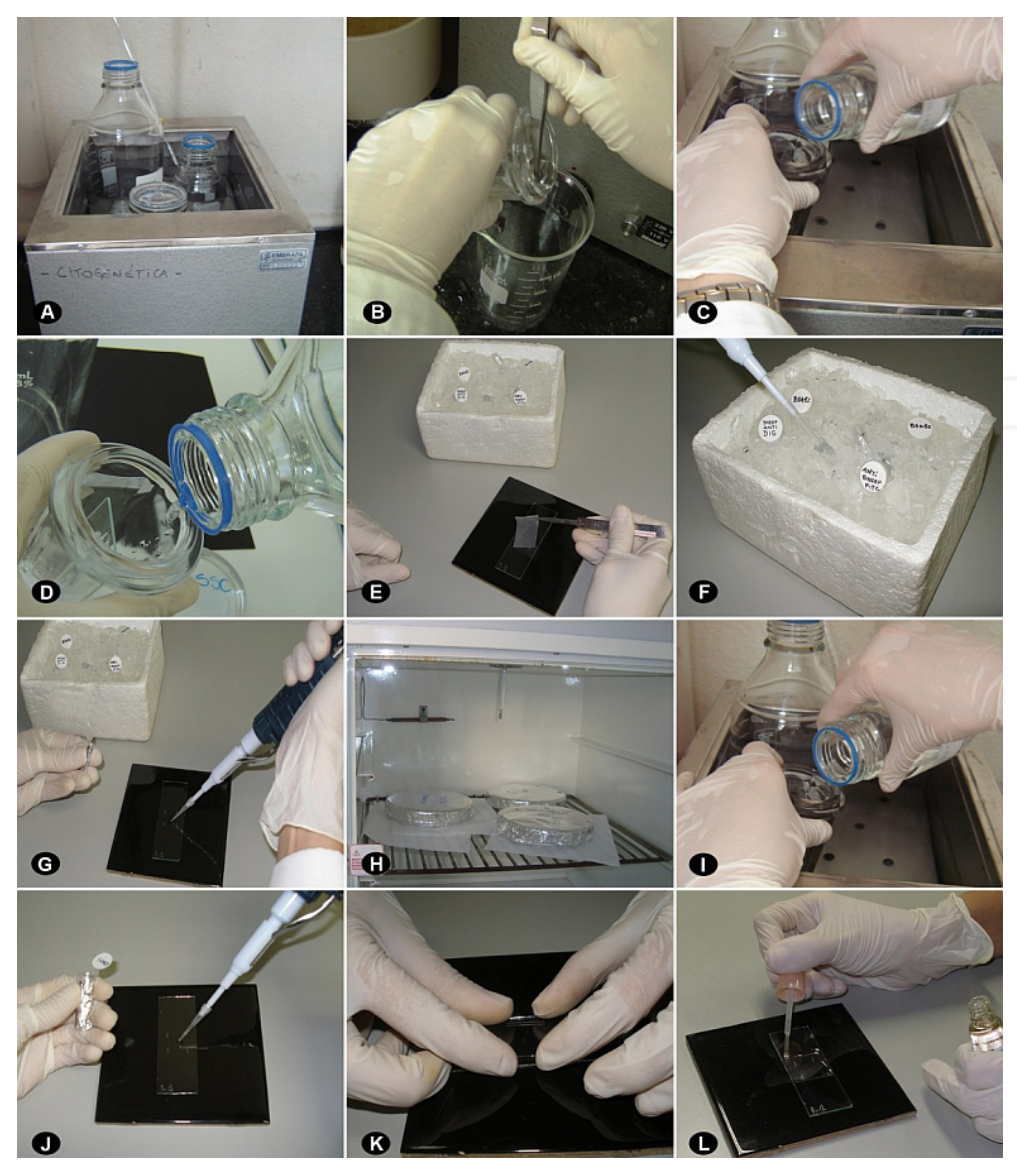

Figure 8. Post-hybridization baths and probe detection. (A) Washing of the slides in a water bath at $42^{\circ} \mathrm{C}$. (B) Disposal of the saline-sodium citrate (SSC) solution. (C) Addition of the next SSC solution. (D) Addition of $4 \times S S C+0.1 \%$ Tween 20 at room temperature. (E) Addition of 5\% bovine serum albumin (BSA) for the blocking step. (F) Preparation of the antibody solution. (G) Addition of the antibody solution and covering with a plastic coverslip. (H) Incubation of the slides during the detection step at $37{ }^{\circ} \mathrm{C}$. (I) Washing the Wash the slides three times for 10 min each in $4 \times$ SSC $+0.1 \%$ Tween 20 at $42^{\circ} \mathrm{C}$. These washes are needed for removing the excess of antibodies (Fig. 8I). Figures A, B, C, D, H and I: Sandra P. Brammer; E, F, G, J, K and L: Ana R. Oliveira \& Ana C. Brasileiro-Vidal.

A metaphase cell of triticale $(2 n=56)$ is shown with the 14 chromosomes from rye detected by GISH in Fig. 9. This cell was hybridized with blocking DNA of wheat and rye DNA probe labeled with digoxigenin and detected with FITC (fluorescein isothiocyanate). The chromosomes are counterstained with DAPI (Fig. 9A). Fig. 9B shows the image capture of the same chromosomes with the fluorescence filter for FITC; and, in Fig. 9C, is shown the superposition of both images. 

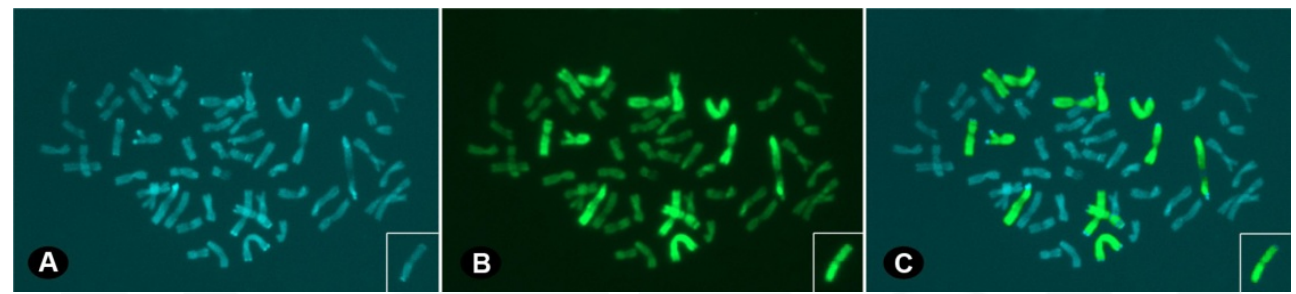

Figure 9. Genomic in situ hybridization $(\mathrm{GISH})$ in a triticale cell $(2 n=56)$, using rye DNA as probe ( $g r e e n)$ and wheat DNA as blocking DNA. Chromosomes were counterstained with DAPI (blue). The same cell is represented in A (DAPI), $B(F I T C)$ and $C\left(A+B\right.$ image merging). The detail in A, B and C shows the $14^{\text {th }}$ rye chromosome of the same cell. Ana $C$. Brasileiro-Vidal.

\section{Final considerations}

The Triticeae wild relatives continue to be important sources of genes for introducing agronomically desirable traits into common wheat and durum wheat (Triticum durum) [20-21]. Thus, alien gene transfer into common wheat via cross-species hybridization makes possible the resistance increasing to biotic and abiotic stresses as well as the quality improving [22-23]. Several species such as of the genera Aegilops, Secale and Thinopyrum have been extensively used in hybridizations with common wheat, thus proving to be a valuable source of genes [3, 24-25].

In all these examples, the genomic in situ hybridization methodology can be used to establish the cytogenetic constitution of interspecific or intergeneric hybrids. In addition, this technique allows for a fine-scale characterization of the chromosome structure. Currently, the technique has been used in parallel to different strategies, such as C-banding, high molecular weight (HMW) glutenin subunits, FISH with BACs (bacterial artificial chromosomes), southern blot and molecular markers, in order to confirm the alien gene introgression into the wheat genome [26-29]. Besides, the GISH has been also collaborated in investigations about the evolutionary origin of common wheat and the genome-wide transcriptional dynamics [30].

\section{Acknowledgements}

The authors thank the following Brazilian agencies for financial support: Conselho Nacional de Desenvolvimento Científico e Tecnológico (CNPq); Coordenação de Aperfeiçoamento de Pessoal de Nível Superior (CAPES); and Fundação de Amparo à Ciência e Tecnologia do Estado de Pernambuco (FACEPE). 


\section{Author details}

Sandra Patussi Brammer'1, Santelmo Vasconcelos², Liane Balvedi Poersch², Ana Rafaela Oliveira ${ }^{2,4}$ and Ana Christina Brasileiro-Vidal ${ }^{2}$

1 Brazilian Agricultural Research Corporation - Embrapa Wheat, Passo Fundo, Brazil

2 Federal University of Pernambuco, Recife, Brazil

3 Federal University of Rio Grande do Sul, Porto Alegre, Brazil

4 Federal Rural University of Pernambuco, Recife, Brazil

\section{References}
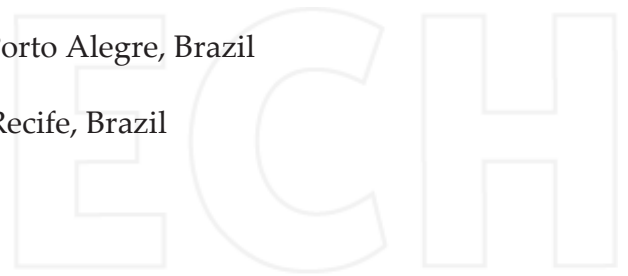

[1] Oettler G. Crossability and embryo development in wheat-rye hybrids. Euphytica 1983;32(2) 593-600.

[2] Prieto P, Ramírez C, Cabrera A, Ballesteros J, Martín A. Development and cytogenetic characterisation of a double goat grass-barley chromosome substitution in tritordeum. Euphytica 2006;147(3): 337-342.

[3] Molnár-Láng M, Cseh A, Szakács E, Molnár I. Development of a wheat genotype combining the recessive crossability alleles $\mathrm{kr} 1 \mathrm{kr} 1 \mathrm{kr} 2 \mathrm{kr} 2$ and the 1BL.1RS translocation, for the rapid enrichment of 1 RS with new allelic variation. Theoretical and Applied Genetics 2010;120(8) 1535-1545.

[4] Molnár-Láng M, Kruppa K, Cseh A, Bucsi J, Linc G. Identification and phenotypic description of new wheat: six-rowed winter barley disomic additions. Genome 2012;55(4) 302-311.

[5] Sybenga J. Cytogenetics in Plant Breeding. New York: Springer-Verlag; 1992.

[6] Figueroa DM, Bass HW. A historical and modern perspective on plant cytogenetics. Briefings in Functional Genomics 2010;9(2) 95-102.

[7] Hall BD, Spiegelman S. Sequence complementarity of T2-DNA and T2-specific RNA. Proceedings of the National Academy of Sciences of the United States of America 1961;47(2) 137-146.

[8] Langer PR, Waldrop AA, Ward DC. Enzymatic synthesis of biotin-labeled polynucleotides: novel nucleic acid affinity probes. Proceedings of the National Academy of Sciences of the United States of America 1981;78(11) 6633-6637.

[9] Ohmido N, Fukui K, Kinoshita T. Recent advances in rice genome and chromosome structure research by fluorescence in situ hybridization (FISH). Proceedings of the Japan Academy, Series B 2010;86(2) 103-116. 
[10] Singh RJ. Plant Cytogenetics, 2nd edition. Boca Raton: CRC Press; 2003.

[11] Schwarzacher T, Anamthawat-Jonsson K, Harrison GE, Islam A, Jia JZ, King IP, Leitch AR, Miller TE, Reader SM, Rogers WJ, Shi M, Heslop-Harrison JS. Genomic in situ hybridization to identify alien chromosomes and chromosome segments in wheat. Theoretical and Applied Genetics 1992;84(7) 778-786.

[12] Brasileiro-Vidal AC, Cuadrado A, Brammer SP, Benko-Iseppon AM, Guerra M. Molecular cytogenetic characterization of parental genomes in the partial amphidiploid Triticum aestivum $\times$ Thinopyrum ponticum. Genetics and Molecular Biology 2005;28(2) 308-313.

[13] Zhou S, Li K, Zhou G. Analysis of endosperm development of allotriploid × diploid/ tetraploid crosses in Lilium. Euphytica 2012;184(3) 401-412.

[14] Markova M, Vyskot B. New horizons of genomic in situ hybridization. Cytogenetic and Genome Research 2009;126(4) 368-375.

[15] Bonato ALV. Extração de DNA genômico de cereais de inverno na Embrapa Trigo comunicado técnico online 235. Passo Fundo: Embrapa Trigo; 2008. http:// www.cnpt.embrapa.br/biblio/co/p_co235.htm (accessed 25 July 2012).

[16] Michaels SD, John MC, Amasino RM. Removal of polysaccharides from plant DNA by ethanol precipitation. Biotechniques 1994;17(2) 274-276.

[17] Schwarzacher T, Heslop-Harrison, P. Practical in situ hybridization. Oxford: BIOS Science Publishers; 2000.

[18] Heslop-Harrison JS, Schwazarcher T, Anamthawat-Jónssonn K, Leitch AR, Shi M. In situ hybridization with automated chromosome denaturation. Technique 1991;3(1) 109-115.

[19] Pedrosa A, Jantsch MF, Moscone EA, Ambros PF, Schweizer D. Characterisation of pericentromeric and sticky intercalary heterochromatin in Ornithogalum longibracteatum (Hyacinthaceae). Chromosoma 2001;110(3) 203-213.

[20] Oliver RE, Xu SS, Stack RW, Friesen TL, Jin Y, Cai X. Molecular cytogenetic characterization of four partial wheat-Thinopyrum ponticum amphiploids and their reactions to Fusarium head blight, tan spot, and Stagonospora nodorum blotch. Theoretical and Applied Genetics 2006;112(8) 1473-1479.

[21] Kwiatek M, Błaszczyk L, Wiśniewska H, Apolinarska B. Aegilops-Secale amphiploids: chromosome categorisation, pollen viability and identification of fungal disease resistance genes. Jounal of Applied Genetics 2012;53(1) 37-40.

[22] Sepsi A, Molnár I, Molnár-Láng M. Physical mapping of a 7A.7D translocation in the wheat-Thinopyrum ponticum partial amphiploid BE-1 using multicolour genomic in situ hybridization and microsatellite marker analysis. Genome 2009;52(9) 748-754. 
[23] Kang H, Zeng J, Xie Q, Tao S, Zhong M, Zhang H, Fan X, Sha L, Xu L, Zhou Y. Molecular cytogenetic characterization and stripe rust response of a trigeneric hybrid involving Triticum, Psathyrostachys, and Thinopyrum. Genome 2012;55(5) 383-390.

[24] Rawat N, Neelam K, Tiwari VK, Randhawa GS, Friebe B, Gill BS, Dhaliwal HS. Development and molecular characterization of wheat-Aegilops kotschyi addition and substitution lines with high grain protein, iron, and zinc. Genome 2011;54(11) 943-953.

[25] Fu S, Lv Z, Qi B, Guo X, Li J, Liu B, Han F. Molecular cytogenetic characterization of wheat-Thinopyrum elongatum addition, substitution and translocation lines with a novel source of resistance to wheat Fusarium Head Blight. Journal of Genetics and Genomics 2012;39(2) 103-110.

[26] Han F, Liu B, Fedak G, Liu, Z. Genomic constitution and variation in five partial amphiploids of wheat-Thinopyrum intermedium as revealed by GISH, multicolor GISH and seed storage protein analysis. Theoretical and Applied Genetics 2004;109(5) 1070-1076.

[27] Kato A, Vega JM, Jonathan FH, Lamb C, Birchler, JA. Advances in plant chromosome identification and cytogenetic techniques. Current Opinion in Plant Biology 2005; 8 (2) $148-154$.

[28] Sepsi A, Molnár, I, Szalay, D, Molnár-Láng, M. Characterization of a leaf rust-resistant wheat-Thinopyrum ponticum partial amphiploid BE-1, using sequential multicolor GISH and FISH. Theorical and Applied Genetics 2008;116(6) 825-834.

[29] Wang L, Yuan J, Bie T, Zhou B, Chen P. Cytogenetic and molecular identification of three Triticum aestivum-Leymus racemosus translocation addition lines. Journal of Genetics and Genomics 2009;36(6) 379-385.

[30] Qi B, Huang W, Zhu B, Zhong X, Guo J, Zhao N, Xu C, Zhang H, Pang J, Han F, Liu B. Global transgenerational gene expression dynamics in two newly synthesized allohexaploid wheat (Triticum aestivum) lines. BMC Biology 2012; 10(3). 